\title{
The commons: opening and enclosing non-commodified space
}

\author{
James Arvanitakis, Faculty of Humanities and Social Sciences, University of \\ Technology Sydney
}

\section{Introduction}

This paper begins with a simple question-'how can you steal something that no one owns'? Though a simple question, the answer is complicated, for the stealing of 'things' owned by no one explains an important aspect of capitalism's insatiable appetite.

Historically the conditions for industrialisation and market economies were created by capital through the colonisation of common lands and common modes of productionthings that are shared but not owned. And this is an appetite that shows no sign of abating. This paper looks at the concept of the commons as aspects of our lives that no one owns but that everyone enjoys. Today the commons are constantly under siege. However, this claim does not only refer to 'physical’ commons; here, I extend the concept of non-commodified 'spaces' into the cultural sphere.

By outlining how capital continually works to enclose the commons-both physical and cultural-this paper aims to present a key contest occurring between neoliberalism and today's social justice movements. This conflict is based on the manufacturing of scarcity through enclosure versus the concept of abundance through sharing and cooperation. In this paper I define abundance as a sense that there is 'enough to share,' and separate it from material wealth. This may explain why certain societies have large amounts of material wealth but lack abundance, and thus experience a sense of scarcity. In this paper I argue that the 'scarcity' that exists in many parts of our world today is manufactured, and results not from the 'tragedy of the commons,' but rather from the 'tragedy of 
enclosure.' The purpose then, is to identify the source of this enclosure, and why it continues, as well as describe potential paths to challenge it. Before doing so, however, I would like to better examine the concept of the commons.

\section{Understanding the commons}

While references to the commons can be traced back to ancient Rome, clearly physical commons such as air and water existed long before the concept was ever 'defined.' This category also encompasses the 'biodiversity' or 'genetic' commons, which include classifications such as the human genome that makes us a unique species, as well as the world's biological diversity (Shiva 2000). These are aspects of the physical environment that, historically, no one owns but we all enjoy.

While we usually think of 'physical or environmental commons,' Bollier (2002) argues that there are also institution-based commons. I identify these as 'institutional commons' that can include 'public goods' such as public education, health, the infrastructure that allows our society to function (that is, water delivery and sewerage systems), and even public space. Bollier (2002) and Lessig (2004) extend the concept of the institutional commons to include literature, music, the performing and visual arts, radio, community arts, and sites of heritage. This conceptualisation of the commons may also be expanded to the 'cultural' sphere. Therefore the commons can include human relationships such as the need for safety, trust, shared intellect, as well as simply cooperation. Briefly focussing on 'safety,' for example, I would argue that safety as a commons can be understood as both a sense of peace and an absence of fear. It can be thought of as mediated by a sense of belonging that allows members of communities to interact with each other (Rustomjee 2001).

Cultural commons such as safety represent a form of biopolitics that promotes the potential for greater cooperation. That is, if I feel safe within my community, even when surrounded by strangers, then I am likely to cooperate with them. Safety can produce relationships that are non-hierarchical and inclusive, allowing communities to work together to overcome scarcity, crisis and fear (Hardt and Negri 2004, xvi). 
According to The Ecologist (1996, 6-9), commons have a number of definitive characteristics that appear to cut across all categories. These include the position that commons cannot be commodified, and, if they are, they cease to be commons and become commodities. Further, though neither public nor private, commons tend to be facilitated by local communities. While this may be true to a degree, commons cannot be exclusionary. ${ }^{1}$ That is, if commons have fences or borders erected around them they become private property. In many societies a central government 'manages' the commons; however, realistically they have been inherited from past generations and any governing body only holds them in trust for the broader public, as well as for future generations. ${ }^{2}$ Commons are not scarce but rather abundant, and, in fact, if facilitated and managed properly they can overcome scarcity. Finally, commons can be understood to be ubiquitous, functioning all the time and every day.

The Ecologist claims that 'The commons is the social and political space where things get done and where people have a sense of belonging and an element of control over their lives,' providing ‘sustenance, security and independence' (1996, 6-7). Thus, what a community shares can include the need for trust, cooperation and human relationships. That is, these are the very foundations of what makes 'a community' rather than a group of individuals living in close proximity to each other. Rather than being driven by self interest and competition, the notion of the commons is based on communal and altruistic cooperation. For communities to use and maintain the commons, cooperation, collaboration and communication is required (Hardt and Negri 2004, Xv). This understanding of the commons involves people operating on a collective rather than merely individualistic level.

\section{The tragedy of the commons}

In Garret Hardin's (1968) original work in the area, the concept of the 'tragedy of the commons' is focused on the physical (environmental) commons. Based on a belief in

\footnotetext{
${ }^{1}$ Later in this paper I argue that certain commons such as 'financial cooperatives' can operate under market conditions. Consequently, while some commons such as air cannot be exclusionary, the use of others needs to be negotiated with their 'managers.'

${ }^{2}$ Here the term 'manage' is used in its most generic sense- - that is, to direct or control the use of something. Unless otherwise specified, there are no financial implications intended.
} 
'methodological individualism' (Jacobs 1997) and the dominance of the self-interested individual, Hardin argues that humanity inevitably exploits resources that are not assigned clear property rights, including the commons. Hardin proposes that 'the survival of the commons depends on "mutual coercion mutually agreed on."' Hardin also argues that some kind of 'administrative elite' should undertake this 'coercion,' although today this appears to have been replaced by the disciplines offered by 'the market' and its proponents. One example can be found in Sklair's (1996; 2000) 'transnational capital class' (TCC), those elite managers, policy advisers and politicians that actively promote the agenda of neoliberalism and free market solutions to all areas of life. The TCC offer 'the market' as the means to better manage the commons.

Although the managerial justification for the enclosure of the commons can be found in Hardin's 1968 essay, Hardt and Negri (2004) believe that the commons were essentially destroyed with the advent of private property. Such a position echoes well-established arguments by Thomson (1963) who described the commodifying tendencies of capital, including the enclosure of the commons. Goldman $(1997,1)$ notes that while Hardin’s position was never based on empirical evidence and has been continuously 'debunked,' the assumptions underpinning it persist and continue a long neoliberal tradition that suggests we must commercialise to get the best out of people. As a result, much of what has traditionally been thought of as the commons has disappeared. Today there is very little left in our physical world that is shared, and there is little understanding of forms of ownership that do not rely on defined private property rights (Jacobs 1997). In fact, the majority of economics textbooks state that if private property rights are not or cannot be appropriately defined, then market failure will result. ${ }^{3}$

This was highlighted in a recent debate in Australia over indigenous communal-owned lands. Senior members of the federal government, including the Minister for Health, Tony Abbott, and the Prime Minister, John Howard, argued that communal land ownership continues to hold indigenous communities back from economic development (Wood 2003, 13; Metherell 2004a, 6). In fact, Tony Abbott branded native title as

\footnotetext{
${ }^{3}$ For example, see McTaggart et al (1999) for a one-dimensional perspective on this topic.
} 
'economically useless' and called for it to be replaced (Wood 2003, 13). According to the Prime Minister, this would breed 'a more entrepreneurial' culture (Metherell 2004b, 7). These discussions have been welcomed by senior Labor Party officials, including President Warren Mundine, himself an indigenous Australian (Karvelas 2004, 4), although these positions have been disputed by many other indigenous leaders, such as Yunupingu (2005). ${ }^{4}$

\section{Cultural implications}

A number of important cultural implications follow Hardin's 'tragedy of the commons' (1968). To begin with, there is the connotation that the community cannot manage communally based resources. This type of argument contains a clear cultural statement that 'human nature' means we are 'greedy' and dominated by self-interest. As The Ecologist notes, the original belief presented by Hardin is that profit is the only 'operating social value' $(1996,13)$. The general argument, then, is that environmental destruction should be blamed on the selfishness of people (Goldman 1997).

The second implication follows the first: the commons are always areas of potential conflict. That is, under the market logic, a lack of private property rights means that 'resources' are subject to constant dispute. We must be protected from ourselves and our self-interest or all resources, both physical and institutional, will increasingly become scarce and conflict will follow. In fact, in a society whose consciousness is dominated by commodity fetishism and materialistic goals, we are discouraged from the belief that we have things in common beyond self interest (Bollier 2002).

This is elucidated by Ostrom and Thrainn in terms of the 'prisoner's dilemma' — 'if I don't others will, so I'd better get in first' $(1990,3) .{ }^{5}$ The perspective inherent in the

\footnotetext{
${ }^{4}$ Similar proposals have been presented regarding Pacific island countries as a path out of their 'economic woes.' Conservative commentator, Helen Hughes $(2004,15)$, argues for the abandoning of communal land ownership for individual property rights. Much like the Australian indigenous system, communal land ownership throughout the Pacific is seen to be the source of economic backwardness and corruption that can only be overcome by appropriate private property rights and free market measures (Hughes 2004). Recently, the Australia Institute has sponsored a response to such proposals (Fingleton 2005).

${ }^{5}$ The concept of the 'prisoner's dilemma' presents a situation where two suspects arrested by police are held but with insufficient evidence for a conviction. The prisoners have been separated and the police visit
} 
prisoner's dilemma has important cultural consequences for the institutional commons. Here citizens discard public institutions in favour of private ones because there is a general feeling that others are doing so and neglect is likely to follow. The abandonment of public institutions is facilitated by the government's purposeful disregard of them, creating 'spirals of neglect.' After ignoring the need to increase resources to public institutions, the government justifies further neglect by the fact that citizens are abandoning these organisations - a process driven by neglect in the first place.

For example, we have seen increased funding of private schools over public institutions. The result is that the public education system is being abandoned as parents are left with the (inevitable) decision to support the public education (a commons), at the risk that their children will not receive an education equivalent to that offered by private institutions. This creates a culture of competition that inspires agents (in this case parents) to abandon and attack the commons (of public education) because of the fear that others are about to do the same. ${ }^{6}$

This culture of competition, greed and conflict leads to an institutional reliance on the markets. The natural extension, then, is to commercialise the commons—run them like a business-to prevent their over-exploitation from greed or neglect by disinterested bureaucrats. To achieve stability, communal institutions should be replaced with private ownership which will assist in reversing the 'actions of the world's majority who blindly think they have the freedom to overgraze, over-consume and over-breed' (Goldman 1997, 4). ${ }^{7}$

each independently and offer them the same deal: if one testifies for the prosecution against the other and the other remains silent, the silent accomplice receives the full 10-year sentence and the betrayer goes free. The prisoners are best served by both keeping silent but a lack of trust is likely to result in each prisoner attempting to betray the other first.

${ }^{6}$ The issue of funding of the Australian schooling system is hotly debated with pro-public and pro-private school lobby groups presenting different 'statistics' to reveal the 'true' figures. See, for example, Centre of Independent Studies (http://www.cis.org.au/) compared to the Australian Council of State Schools (http://www.acsso.org.au/). Here I am responding to the trend of increasing funding of private schools identified by Burke (2004a; 2004b).

${ }^{7}$ Hartmann (2004) has extended this position by arguing that we have seen the emergence of 'the greening of hate'; that is, environmental problems have been blamed on the over-breeding of the poor rather than on any over-use of the resources within high-income nations. 
The notion that the privatisation of the global commons is the key to their protection is a recurring theme in much of the neoliberal literature. For example, a 2002 report from Britain’s Royal Society criticises government-run conservation programs, development aid, protected areas and even plant gene banks, and claims that it is time 'for capitalism to take charge' (cited in Pearce 2002, 10). According to the report, the environment should be 'parcelled out to the private sector, with market forces influencing everything from cleaning up our rivers and the atmosphere to protecting forests and soils’ (Pearce 2002, $10)$.

\section{Tragedy of enclosure}

In response, The Ecologist $(1996,15)$ argues that we are not seeing the tragedy of the commons, but rather a 'tragedy of enclosure,' as it is the commodification, privatisation and enclosure of the commons that causes a crisis of scarcity. This position can be confirmed by following the basic laws of 'supply and demand' economics that characterises the trade of commodities. The scarcer commodities are, the higher their value will be. Accordingly, to maximise profits by demanding higher prices, it suits the owners of resources to 'manufacture scarcity' (Farhat 2001, iii). This does not occur when the commons operate; rather it occurs when the commons are enclosed.

For example, Farhat (2001) argues that one of the most pressing environmental crises today results from the ongoing erosion of the earth's genetic resources. This is causing myriad environmental and social problems, including declining diversity in food crops that offer less protection from disease, and pest infestation. The cause of this decline is related to the commodification of plants and seed varieties that were once openly shared as commons, but are now traded as commodities, dramatically reducing their availability.

However, this is not just a scarcity of natural resources and other physical commons, but scarcity in the broader sense. This is a theme identified by Bauman, who argues that we are witnessing the disappearance or a scarcity of the 'public sphere' $(1999,69)$. Bauman describes the public sphere as the area of legitimate public discourse. Bauman's position is that we are seeing the colonisation of the public sphere and a re-definition of the 
'notoriously mobile boundary' between the public and the private (1999, 70). This has obvious links to Habermas's focus on the structural change of the public sphere under the contemporary era of state capitalism and the increasingly powerful positions of economic corporations in public life (1962). In The Structural Transformation of the Public Sphere (1962), Habermas argued that economic and governmental interests have taken over the public sphere, while citizens have become content to be (primarily) consumers of goods, services, political administration and spectacle.

This enclosure of the public sphere is continuous, recurring, and takes many forms. For example, in response to former U.S. anti-terrorist official Richard Clarke's criticisms of White House reaction to the 2001 terrorist attacks and general lack of policy in this area, the White House organised a multi-level assault on his personality rather than on 'the substance of his contentions' (Allen 2004, 39). This is evidence of the crisis in the public sphere identified by Bauman (1999, 69), where the focus on policy (or Politics) has become subsumed by the issue of personality (or politics). That is, enclosure of the public sphere has seen Politics replaced by politics. Consequently, for the commons, life today is precarious and subject to the constant threat of enclosure and commodification. While there has always been a tension between the commons and the market, the privileging of free market fundamentalism has seen both the expansion of marketisation and the ‘commodification of everything' (Barber 1998).

\section{The commons/commodity typology}

Before proceeding to discuss the defence of the commons by today's resistance movements, I would like to introduce a typology that outlines the arguments presented. It is important to acknowledge that any typology is both a simplification and a generalisation of the arguments that are presented. Likewise, it is highly unlikely that any typology has the ability to cover all cases; therefore, exceptions are expected to arise. Furthermore, it is also important to note that I am not attempting to draw simple binaries between the different categories. Rather, the purpose is to highlight the relationships between the groupings I have identified. As Davis (2001) notes, binaries often act to simplify complex phenomena. For example, any transaction that takes place should be 
considered along a continuum divided between commodities and the exchange of commons via non-commercial transactions (Davis 2001). We can thus see the commons operating within the market system as well as outside it. Rather than drawing binaries, my purpose is to describe such a continuum.

The commons/commodity typology draws two broad distinctions, and is thus divided along a classic $\mathrm{x}-\mathrm{y}$ axis format (see Figure 1). The $\mathrm{x}$ axis is the division between commodities and commons. On the extremes there exist 'pure' commons and commodities. On the commons side, this may include either physical (such as air), institutional (a community library) or cultural commons (such as trust or hope). At the other extreme, there are pure commodities such as foreign-exchange transactions. The y axis represents the separation of the 'market' from not only the economy but also wider society. This is a feature of the free market fundamentalism that is common in today's neoliberalism and has seen the market become the metaphor for the economy (Milberg 2001, 407). There are ‘purely’ societal-based organisations (publicly owned health centres, for example) at one end and solely market-based organisations (such as the stock market) on the other. The four zones of the typology are summarised in Table 1. 
Figure 1: Commons/commodity typology

\begin{tabular}{c|c}
$\begin{array}{c}\text { Neoliberal capitalism } \\
\text { Zone 1 }\end{array}$ & $\begin{array}{c}\text { Market } \\
\text { Cooperatives / } \\
\text { Mutually owned organisations } \\
\text { Zone 3 }\end{array}$ \\
$\qquad \begin{array}{c}\text { Regulated markets } \\
\text { Zone 2 }\end{array}$ & $\begin{array}{c}\text { Commons } \\
\text { Commity based/ } \\
\text { Non-economic open-space } \\
\text { (CGM) } \\
\text { Zone 4 }\end{array}$ \\
Society
\end{tabular}

Figure 2: Examples of commons/commodities

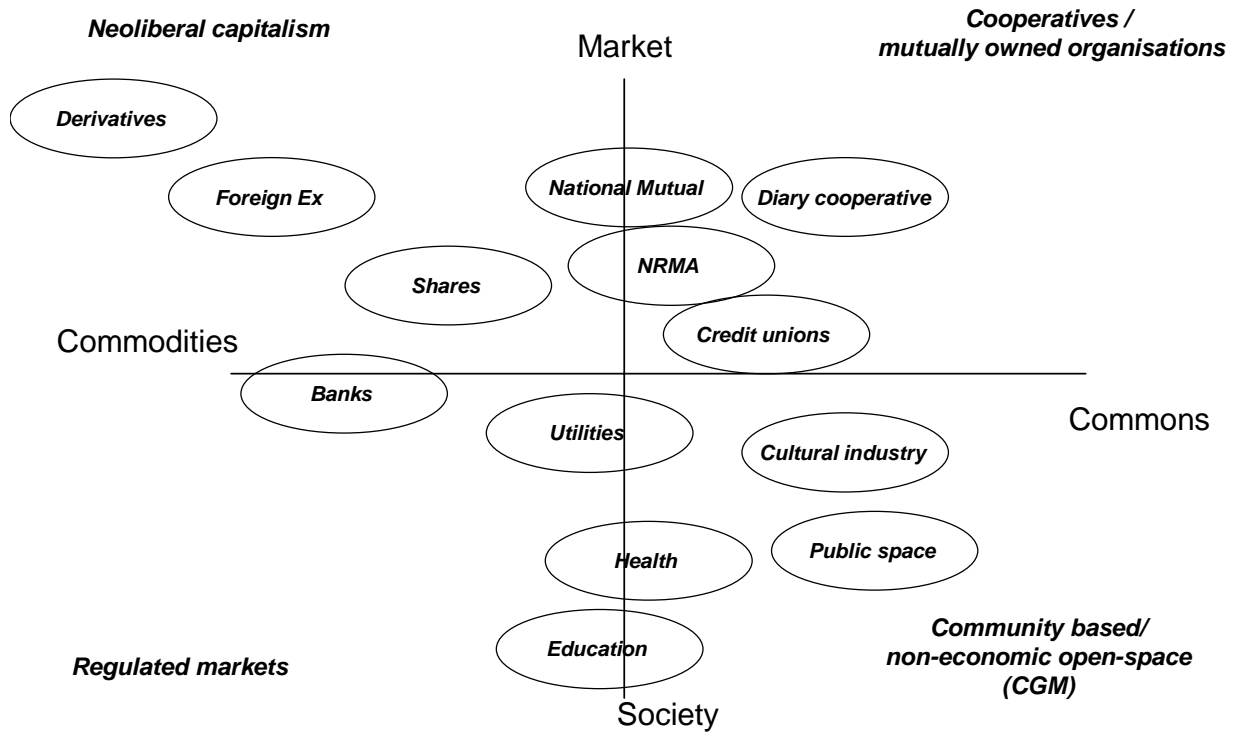


Table 1: Commons/commodity typology

\begin{tabular}{|c|c|c|}
\hline Zones & Description of Zones & $\begin{array}{l}\text { Examples of } \\
\text { Zones }\end{array}$ \\
\hline $\begin{array}{l}\text { Zone 1: } \\
\text { Market- } \\
\text { Commodity }\end{array}$ & $\begin{array}{l}\text { Neoliberalism } \\
\text { This is the zone in which neoliberal capitalism } \\
\text { operates. } \\
\text { This is the space of the free market that operates with } \\
\text { little or no involvement from outside influences. Here } \\
\text { markets and commodities are seen to have little (if any) } \\
\text { connection to wider society. The central goal is profit } \\
\text { or return on investment. } \\
\text { The image of the individual is one of atomised self } \\
\text { interest. Only by pursuing self interest does society } \\
\text { operate appropriately with a functioning community. }\end{array}$ & $\begin{array}{l}\text { Capital markets } \\
\text { Financial } \\
\text { derivatives and } \\
\text { foreign exchange }\end{array}$ \\
\hline $\begin{array}{l}\text { Zone 2: } \\
\text { Commodity } \\
\text {-Society }\end{array}$ & $\begin{array}{l}\text { Regulated markets } \\
\text { This area sees markets placed within the broader } \\
\text { context of society and community. Here it is } \\
\text { acknowledged that markets need to be regulated to } \\
\text { meet both economic and social goals. }\end{array}$ & $\begin{array}{l}\text { Financial } \\
\text { institutions such as } \\
\text { banks } \\
\text { Privatised utilities } \\
\text { such as electricity } \\
\text { and the } \\
\text { infrastructure that } \\
\text { allows delivery of } \\
\text { water. }\end{array}$ \\
\hline $\begin{array}{l}\text { Zone 3: } \\
\text { Market- } \\
\text { Commons }\end{array}$ & $\begin{array}{l}\text { Cooperatives/mutually owned organisations } \\
\text { This area places community-based resources within the } \\
\text { market context. Here, resources may be used for the } \\
\text { sake of financial gain or profit, but this is placed within } \\
\text { the context of broader communal aims. }\end{array}$ & $\begin{array}{l}\text { Financial } \\
\text { cooperatives such } \\
\text { as credit unions } \\
\text { and other mutually } \\
\text { owned } \\
\text { organisations } \\
\text { including } \\
\text { agricultural } \\
\text { cooperatives } \\
\end{array}$ \\
\hline $\begin{array}{l}\text { Zone 4: } \\
\text { Society- } \\
\text { Commons } \\
\text { Counter- } \\
\text { global. } \\
\text { movement } \\
\text { (CGM) }\end{array}$ & $\begin{array}{l}\text { The commons } \\
\text { Community-based and non-commodified space. This is } \\
\text { the zone in which the CGM operates. } \\
\text { This is a space that is considered outside the market } \\
\text { and is not driven by economic or financial motivations. } \\
\text { The aims are communal or societal. } \\
\text { The individual is seen to be both part of the broader } \\
\text { community while maintaining their singularity. An } \\
\text { open and authentic community is established by } \\
\text { achieving this balance. }\end{array}$ & $\begin{array}{l}\text { Utilities managed } \\
\text { for public interest } \\
\text { such as hospitals } \\
\text { and water } \\
\text { Public space, } \\
\text { national parks }\end{array}$ \\
\hline
\end{tabular}


In addition to the examples noted in table 1, others have been added to the typology to present a broader overview in figure 2. These examples are specifically drawn as ovals to signify my position that no group or 'cluster' fits comfortably or easily within any single zone. Even if it is possible to place a cluster wholly in a single zone, the point at which an individual example fits within the cluster varies significantly.

This point can be explained with an example. To begin with, 'health' is a broad cluster that includes both private and public health care providers. Many hospitals are managed by government-owned organisations with the prime motivation to serve the 'common good' (McAuley 1998). As such, 'health’ available to all primarily aims to serve broader society —and thus fits within Zone $4 .^{8}$ Here the common good is seen to consist of establishing functioning social systems, institutions and environments of benefit to all (McAuley 1998). However, each individual health centre and hospital within the public realm will have different philosophies, and some may have greater community links than others.

This can be contrasted with privately run health care organisations. Such organisations have multiple motivations, which include both the provision of health care and obtaining a profitable return for investors. This is highlighted by one of Australia's leading private health care providers, Mayne Group. Mayne’s mission statement outlines the company’s goals that include 'building on the success of our health care products and services to meet the needs of all our stakeholders' whose number consists of both the consumers of its health products and services and its investors (Mayne Group 2005). For this reason, Mayne's website provides information about the health services it provides alongside 'investor' information including current share price and investment strategies. Operating within this regulated market place, ${ }^{9}$ such privately run organisations place priority not only on profits but also on the health of their customers - two goals that are intimately related. Consequently, the cluster of health spreads across Zone 2 and 4.

\footnotetext{
${ }^{8}$ For example, the State Government of Victoria's 'Metropolitan Health Strategy’ $(2003,14)$ places the needs for the community at the centre of the public health sector.

${ }^{9}$ A list of the large number of legislation administered by the Australian federal Minister for Health and Ageing including that which directly impacts private health providers is listed on the following site: http://www.health.gov.au/internet/wcms/publishing.nsf/Content/health-eta2.htm - February 2005.
} 
This close interrelationship between profits and caring for the health of consumers highlights the continuum identified above. As such, both binaries and simplified positions - for instance, 'public is good' and 'private is bad' — can be avoided. It can be argued, then, that private health providers provide an important service to the broader well being of society as they may fill gaps left by the public system. ${ }^{10}$

Figure 2 also portrays the close link between society and the economy. Here the economy is observed and managed within the context of broader societal goals. The economy, society, nature and politics are not seen as being separate spheres. It is important to note that while I concentrate on the physical sphere, the typology can also be extended to the cultural sphere. For example, it would be possible to draw a continuum between open sharing of knowledge and the strict application of intellectual property where all knowledge is commodified. However, such a discussion is beyond the scope of this paper.

\section{Enclosing the commons}

As noted, under neoliberal capitalism the commons are constantly under threat as two simultaneous processes emerge. The first is the separation of the economy from society. This reaches a point at which 'the market' becomes a metaphor for the economy as realms considered outside its domain are slowly subsumed (Milberg 2001, 407). The second is neoliberalism's frontier disposition as it moves towards an ongoing commodification and enclosure of the commons. Both are portrayed in Figure 3.

The central theme that emerges in Figure 3 is the hollowing out of Zone 4 and the subsequent expansion of Zone 1. That is, because of neoliberal capitalism's frontier disposition, increasingly fewer resources are considered outside the market's domain and Zone 4 shrinks while Zone 1 inflates. The result is that many commons that were once

\footnotetext{
${ }^{10}$ This example (hopefully) highlights the flexibility of using such a typology. The Mayne Group is traded on the Australian Stock Exchange. Consequently, while the products and services it provides operate within Zone 2, the organisation itself, which involves the commercial trading of its shares, would be classified under commodities and sit within Zone 1.
} 
seen as being beyond the realm of the market have now been commodified and an imbalance has emerged between the market and other forms of ownership (Lessig 2004; Barber 1998). This prompts Bollier $(2002,6)$ to argue that today there is a tendency not to even recognise the existence of commons.

Figure 3: Enclosing the commons

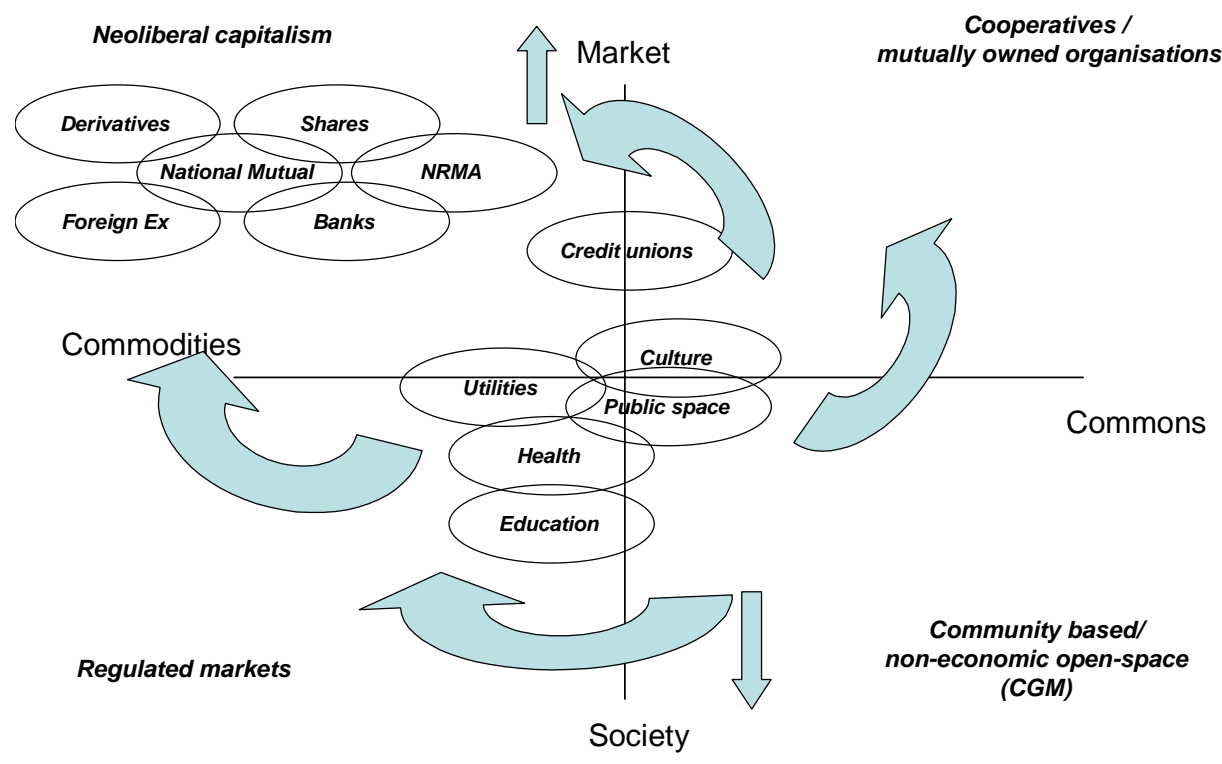

The result of the enclosure, then, is that we are seeing many of the clusters moving from Zone 4 towards Zone 1 either directly (through aggressive privatisation programs) or through stages (such as partial privatisation and public-private partnerships [PPPs]). ${ }^{11}$ It is important to note that I am making no attempt to assign a 'time scale' to the typology. The changes that are taking place are current and both the mode and speed of change within each of the presented clusters varies extensively across time and through space. The experience of each sector within different nations would also be significantly different. For example, the banking sector in Australia moved relatively quickly from Zone 2 to Zone 1, while once exclusively public goods, such as education, have experienced a slower transition. Water privatisation has not yet occurred in Australia, but has occurred elsewhere in the world.

\footnotetext{
${ }^{11}$ PPPs can be defined as any collaboration undertaken between public bodies (including local councils or state and national governments) and private companies (Osborne 2000, 11)
} 
To highlight the hollowing-out of Zone 4, again I will briefly return to the example of health care system in Australia. The issue of privatising the Australian health care system and its consequences is discussed by Brooks $(1999,321)$. Noting that this issue reflects a global trend over the past few decades, Brooks describes how private hospitals have stepped into areas that were once dominated by public providers, including research foundations. This has been driven, in part, by the decision of governments to reduce funding in areas that once were priorities, due to the dominance of budgetary fiscal responsibility that has come to dominate economic orthodoxy since the late 1970s (Brooks 1999, 321).

Such trends continue and are being pursued through a wide variety of mechanisms including PPPs. This allows the further hollowing out of Zone 4 as many relationships established through PPPs give priority to the private sector in accessing research gains. This is particularly evident in the private-public partnerships that have become the widely accepted in university research departments (Bollier 2002). This removes knowledge from the commons (Zone 4) and commodifies it as intellectual property (represented in Zone 1).

\section{Reclaiming the commons}

The concept of the commons is an intellectual thread that links global justice advocates around the world — both on a global and local level. I use the term 'counter-globalisation movement' (CGM) to describe the many different advocates and activists that make up this heterogenous group. This group includes, but is not limited to, those that have been described as ‘anti-globalisation’ activists, individuals who have empathy with such activists but do not take part in protests, and more formal non-government organizations, such as the ones discussed below. The question is 'counter to what'? My answer is counter to the enclosure of neoliberal capitalism and its processes of enclosure and exclusion. 
Simultaneously, the project of neoliberal capitalism seems focussed in enclosing these commons. In fact, as local communities continually move to open new commons, this actually allows the frontier disposition of neoliberal capitalism to expand. In contrast to this commodification, enclosure, and the exclusion that follows, the counter movement defends and establishes new commons that are open to all. This is a non-commodified space. I argue that this contestation over the commons is a pivotal conflict between the CGM and neoliberalism. The CGM works to defend and open new commonssomething that happens in many different ways and takes many different forms.

Organisations as varied as AID/WATCH, AFTINET, Focus on the Global South, and the Council of Canadians, pursue anti-privatisation campaigns in protection of the commons. ${ }^{12}$ For example, AID/WATCH’s 'Right to Water' campaign raises concerns about the ongoing privatisation of water, including rainwater (AID/WATCH 2005). In 2001, AID/WATCH commenced a review of the policies and programs of international financial institutions, investigating their relationship to private water corporations. AID/WATCH identified a consistent policy recommendation to solve people’s lack of access to safe drinking water by privatising community assets and instituting user-pay systems. ${ }^{13}$ This situation arises because official development assistance (ODA) funds and loans to low-income countries focus on privatisation of water delivery and thus privilege multinational water corporations. The prioritisation of user-pays and profits results in the exclusion of a wide section of the population from a resource once available to all. In response, AID/WATCH argues that water is a commons, not a commodity to be sold and, as a result, available only to the highest bidder.

\footnotetext{
${ }^{12}$ AID/WATCH is a non-government organisation based in Sydney that aims to monitor the development dollar and raise concerns about the commodification of the development assistance program (see www.aidwatch.org.au). AFTINET is the Australian Fair Trade and Investment Network also based in Sydney (www.aftinet.org.au). Focus on the Global South is based in Bangkok, Manila and in India, and looks at a cross section of issues including trade, globalisation and development specifically from the perspective of low-income nations (www.focusweb.org). The Council of Canadians is a Canadian-based organisation also concerned with trade and globalisation (www.canadians.org).

${ }^{13}$ These conclusions were supported by recent work undertaken by Naomi Klein (2005) who concludes that privatisation is the only solution offered to the poor by the world's international financial institutions.
} 
Rather than being limited to a small group of actors, however, this process of reclaiming, protecting or establishing commons is central to the CGM. Szerszynski (1999), for example, analyses contemporary ‘environmental’ protests with a specific focus on 'Reclaim the Streets' (RTS). ${ }^{14}$ Szerszynski argues that such protests operate at the level of what might be called the 'semiotics of the everyday' by moving to reclaim public spaces. ${ }^{15}$ Szerszynski (1999) also feels that these protests spill into the cultural sphere by arguing that they are not only about reclaiming public space, but also the 'life-world.' This is an opening of non-commercial space or commons both in the physical and cultural (life) spheres.

Furthermore, this opening emerges not as a well-defined political project but as autonomous and sometimes spontaneous collective behaviours that stress the commons while, at the same time, defending multiple singularities (Hardt and Negri 2004). This is a different logic to that of neoliberalism as it promotes abundance rather than scarcity. The new form of biopolitics promotes multiple singularities to 'work in common' to establish new commons (Hardt and Negri 2004).

It is here, I argue, that the real project of the CGM emerges. The CGM moves to reestablish non-commodified spaces in areas that the market has enclosed. Figure 4 presents a visual summary of this aspect of the CGM. It also highlights some of the mechanisms used by the CGM including advocating for the Tobin $\operatorname{Tax}^{16}$ and antiprivatisation campaigns at the United Nations, through national forums as well at the local community level (Kingsnorth 2002). Consequently, the abundance created by the CGM takes many different forms. For example, abundance can be created in the material sphere by ensuring access to social services that are well resourced. Likewise, abundance

\footnotetext{
${ }^{14}$ The Reclaim the Streets collective is made up of various groups that come together to 'reclaim public space.' There are many such collectives around the world and they come together in a sporadic fashion. See http://www.reclaimthestreets.net/.

${ }^{15}$ It should be noted that while Szerszynski (1999) uses the label 'environment' to describe the protest, he also notes that such protest groups are not single-issue organizations; rather, they present multi-dimensional symbols.

${ }^{16}$ Tobin Taxes are taxes placed on cross-border currency transactions with the aim of limiting speculation and currency volatility, and promoting longer-term investment and national economic sovereignty (Patomaki 2001). The vision that exists for such a tax is that the revenue raised would be managed by the UN and directed towards global priorities including environmental and human needs.
} 
can also be created in the cultural sphere through the open and cooperative sharing of hope, trust and knowledge. It should also be noted that within this context the market is brought back under the umbrella of the economy and broader society. The market is not seen to exist in its own right, but rather is merely one mechanism to promote the allocation of selected resources.

Figure 4: Commons/Commodity Typology

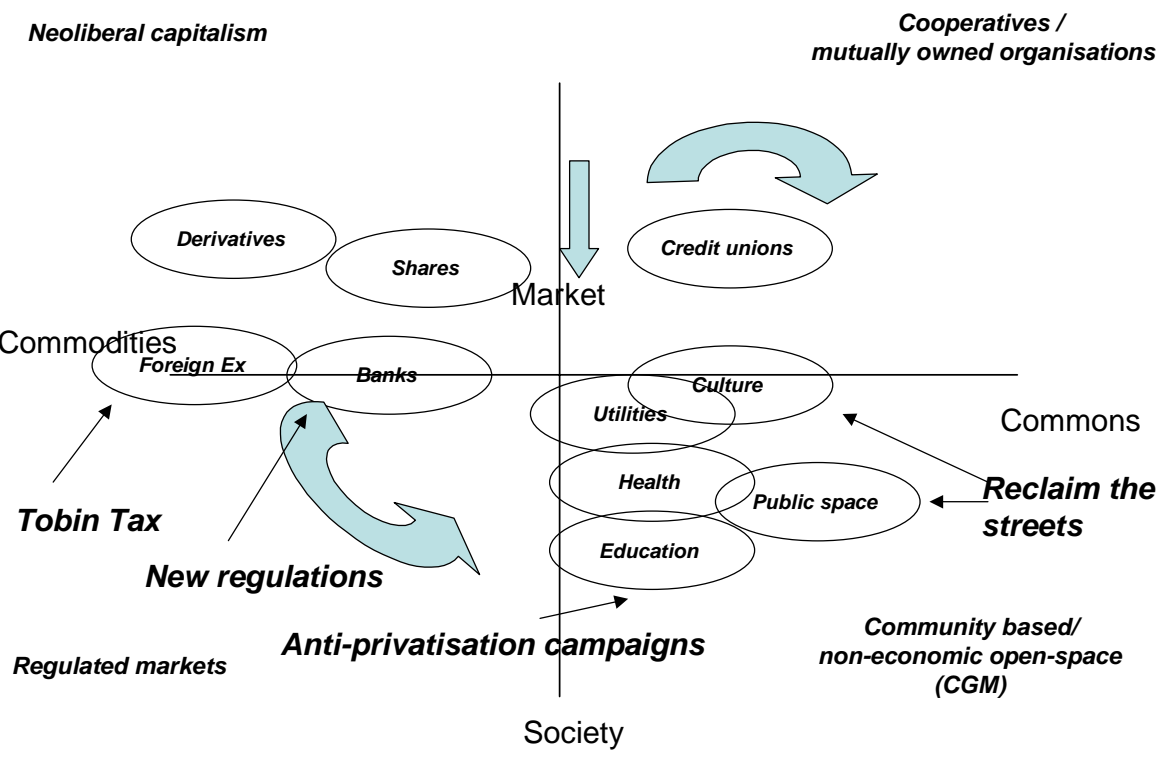

\section{Drawing conclusions}

A number of important conclusions derive from reading the commons/commodities typology. First, this typology highlights the ongoing enclosure and commodification of various commons, such as public health and education systems, has been a slow yet prevalent trend. Furthermore, this trend also reflects a cultural shift. Here, the clear cultural message delivered by Hardin's (1968) tragedy of the commons is that the broader public cannot be trusted to manage resources. Markets become accepted as the only mechanism for distributing resources, and there emerges wide level approval that this can only be achieved through commodification. Evidence from this can be derived from the overwhelming support given to the privatisation of once mutually owned resources, such 
as the NRMA and AMP in Australia. ${ }^{17}$ This point reflects the broader position that the privatisation of public goods is accompanied by the commodification of culture as the market becomes the dominant organisational form.

A third conclusion that can be made is that the typology portrays the ongoing dominance of the Cartesian logic and neoliberalism's frontier disposition. Simultaneously, this also demonstrates the disappearance of the commons as described by Bollier (2002) and Lessig (2004). There is a hollowing out of Zone 4 that occurs as the commons are enclosed despite the efforts of the CGM to stop or alter this process. Finally, the typology also demonstrates a fundamental real project of the CGM and how it works to establish new commons. As discussed earlier, I argue that this is the central intellectual thread that links the heterogenous groups of actors that I have presented as the CGM.

\section{Reference list}

AID/WATCH 2005, AID/WATCH Campaigns [Online] Available at: http://www.aidwatch.org.au/index.php?current=2 [Accessed March 2005].

Australian Stock Exchange and Australian Shareholders' Association, 'Demutalisations since 1985. Avaliable at http://www.delisted.com.au/Demutualised.aspx. Accessed 28 January 2006.

Allen M. 2004, 'The war on a terrorism advisor,' Sydney Morning Herald, 27 March, 39. Barber, B. 1998, 'Democracy at risk: American culture in a global culture,' World Policy Journal, 15.2: Summer 1998, 29-41.

Bauman, Z. 1999, Liquid Modernity, Polity, London and New York.

Bollier, D. 2002, Silent Theft: The Private Plunder of our Common Wealth, Routledge, New York.

Brooks, P.M. 1999, 'The privatisation of teaching hospitals,' Medical Journal of Australia, 170: 321-322.

Burke, K. 2004a, 'How private schools get paid,' Sydney Morning Herald, 16 March. 2004b, 'Pressure on NSW to slash funding for private schools,' Sydney Morning Herald, 16 March.

Davis, J. 2001, 'Gifts and trade,' in Cullenberg, S., Amariglio, J., and Ruccio, D.F. (eds), Postmodernism, Economics and Knowledge, Routledge, London and New York, 475-482.

\footnotetext{
${ }^{17}$ NRMA and AMP were both successful mutually owned organisations that were privatised in the 1990 s. Both de-mutualisations received overwhelming support from former members who were offered 'free shares' in the process. Such de-mutualisation follows on from others and joins the privatisation of publicly owned Australian organisations (Qantas, Commonwealth Bank, NSW GIO and Telstra). See http://www.delisted.com.au/Demutualised.aspx for details - accessed March 2005.
} 
Ecologist, The 1996, Whose Common Future? Reclaiming the Commons, Earthscan Publications, London.

Farhat, R. not dated, Biopiracy: genetic engineering, life patents and the manufacturing of scarcity, AID/WATCH, Sydney.

Fingleton, J. ed. 2005, Privatising land in the Pacific: a defence of customary tenures, Discussion Paper Number 80, June 2005, the Australia Institute, Canberra.

Goldman, M. 1997, “"Customs in common”: the epistemic world of the commons scholars,' Theory and Science, 26.1: 1-37.

Habermas, J. 1991 [1962], The Structural Transformation of the Public Sphere: An Inquiry into a Category of Bourgeois Society Studies in Contemporary German Social Thought, The MIT Press, Cambridge, MA

Hardin, G. 1968, 'The tragedy of the commons,' in Dryzek, J.S., and Schlosberg, D. (eds), 1999, Debating the Earth: The Environmental Politics Reader, Oxford University Press, New York, 23-34.

Hardt, M. and Negri, A. 2000, Empire, Harvard University Press, Cambridge.

—. 2004, Multitude, Penguin, New York.

Hartmann, B. 2004, 'Conserving racism: the greening of hate at home and abroad,' Different Takes, 27, Winter 2004 [Online] Available at:

http://popdev.hampshire.edu/projects/dt/pdfs/DifferenTakes_27.pdf [Accessed November 2004].

Hughes, H. 2004, 'Radical reforms needed to make Pacific viable,' The Courier-Mail, 7 December 2004, 15.

Jacobs, M. 1997, 'Sustainability and markets: on the neoclassical model of environmental economics,' New Political Economy, November: 365-385.

Karvelas, P. 2004, 'Land rights may be privatized,' The Australian, 10 December 2004, 4.

Kingsnorth, P. 2004, One No, Many Yeses: A Journey to the Heart of the Global Resistance Movement, Simon \& Schuster, London.

Klein, N. 2005, 'The rise of disaster capitalism,' The Nation, 2 May 2005, http://www.thenation.com/doc/20050502/klein [Accessed May 2005].

Lessig, L. 2004, Free Culture: How Big Media Uses Technology and the Law to Lock Down Culture and Control Creativity, Penguin, East Rutherford, NJ.

Mayne Group 2004, Mayne Group [Online]. Available at: http://www.maynegroup.com/97.asp [Accessed February 2005].

McAuley, I. 1998, 'Health - a common good,' New Doctor, 68, Summer 1998, [Online]. Available at: http://www.drs.org.au/journal/68/68health.htm [Accessed January 2005].

McTaggart D., Findley C., and Parkin M. 1999, Economics, 3rd Edition, Addison Wesley Longman, Melbourne.

Metherell, M. 2004a, 'Land system holds us back, says Mundine,' The Sydney Morning Herald, 10 December 2004, 6. 2004b, 'Howard backs private gain from black land,' The Sydney Morning Herald, 10 December 2004, 7.

Milberg, W. 2001, 'De-centering the market metaphor in international economics,' in Cullenberg, S., Amariglio, J. and Ruccio, D.F. (eds), Postmodernism, Economics and Knowledge, Routledge, London and New York, 407-430. 
Osborne, S. P. 2000, Public-Private Partnerships: Theory and Practice in International Perspective, Routledge, Oxford.

Ostrom, R.C., and Thrainn, E. eds. 1990, Governing the Commons: The Evolution of Institutions for Collective Action Political Economy of Institutions and Decisions, Cambridge University Press, Cambridge.

Pearce, F. 2002, 'Market forces "are the way to save the planet”,' New Scientist, 175.2350: 10 .

Patomaki, H. 2001, Democratising Globalisation: The Leverage of the Tobin Tax, Zed Books, London and New York.

Rustomjee, S. 2001, 'Exploring social disintegration,' Group Analysis, SAGE Publications, London.

Shiva, V. 2000, Protect or Plunder? Understanding Intellectual Property Rights, Zed Books, London.

Sklair, L. 1996, 'Conceptualising and researching the transnational capitalist class in Australia,' Australian and New Zealand Journal of Sociology, 32.2: 1-19. 2000, The Transnational Capitalist Class, Blackwell Publishers, Sydney, London.

Szerszynski, B. 1999, 'Performance politics: the dramatics of environmental protest,' in Ray, L. and Sayer, A. (eds), Culture and the Economy: After the Cultural Turn, Sage, London, 211-228.

Thompson, E. P. 1963, The Making of the English Working Class, Penguin Books, London.

Wallach, L., and Woodall, P. 2004, Whose Trade Organisation?, The New Press, New York and London.

Wood, A. 2002, 'Individual enterprise the key to progress for Aborigines,' The Australian, 29 April 2003, 13.

Yunupingu, G. 2005, 'Turning back the clock for Aborigines,' Sydney Morning Herald, 11 April 2005, 11. 